\title{
Staphylococcal Penicillinase Plasmids: Studies on the Reversion of a Temperature-sensitive Replication Mutant to Temperature Stability
}

\author{
By L. H. JOHNSTON* AND K. G. H. DYKE \\ Microbiology Unit, Department of Biochemistry, Oxford $O X_{\mathrm{I}} 3 Q U$
}

(Received 28 September 1973; revised 20 December 1973)

SUMMARY

A culture of Staphylococcus aureus harbouring a temperature-sensitive plasmid carrying genes for resistance to penicillin and cadmium ions, loses this plasmid and the associated phenotype when grown at the restrictive temperature. However, incubation at the restrictive temperature in the presence of cadmium ions results in a small number of cadmium-resistant cells. The properties of these surviving cells have been investigated and evidence is presented in support of the hypothesis that at least some of these cadmium-resistant cells are the result of integration of the plasmid into some other replicon, possibly the chromosome.

\section{INTRODUCTION}

In most penicillin-resistant strains of Staphylococcus aureus, the penicillinase structural gene responsible for this resistance is carried on a plasmid (Novick, I963). Present on this same plasmid may be genes conferring resistance to various inorganic ions (Novick \& Roth, 1968) and erythromycin (Mitsuhashi, Hashimoto, Kono \& Morimura, 1963). These plasmids can be divided into at least two groups on the basis of compatibility: a type I and a type II plasmid can be maintained within the same cell but two type I or two type II plasmids cannot be stably maintained (Novick, 1967a, b). One of the possible explanations for these results is that there is a specific site within the cell for the maintenance of each type and that, if this site is occupied, then a second plasmid of the same compatibility group cannot be stably maintained (cf. Jacob, Brenner \& Cuzin, 1963). It is possible that the postulated site is part of the membrane and that this membrane site is essential for replication and segregation of the plasmid.

In the course of investigations on plasmid replication, we isolated a temperature-sensitive mutant of a penicillinase plasmid (Johnston \& Dyke, I97I). Evidence was presented to show that, at the restrictive temperature, the mutant plasmid does not replicate and that, since the bacteria continue to grow and divide, plasmid-negative variants are formed. This mutant plasmid, like that from which it was derived, confers resistance to cadmium ions, so that if the bacterium is grown at the restrictive temperature in the presence of cadmium ions, only revertants that can replicate and express a cadmium-resistance gene will survive. This paper is an account of studies on the properties of such revertants. Our evidence supports the hypothesis that the most common means of reversion to temperature-stable replication of the cadmium-resistance gene results from integration of the entire plasmid into some other replicon - most probably the chromosome.

* Present address: Department of Molecular Biology, University of California, Berkeley, California 94720, U.S.A. 


\section{METHODS}

Chemicals. Ethidium bromide (3,8-diamino-5-ethyl-6-phenyl-phenanthridinium) was a gift of Boots Pure Drug Co. Lysostaphin was from Cambrian Chemicals Ltd, Croydon, Surrey. $2-\left[{ }^{14} \mathrm{C}\right]$ thymidine $(250 \mu \mathrm{Ci} / \mathrm{mg})$ and $6-\left[{ }^{3} \mathrm{H}\right]$ thymidine $(107 \cdot 5 \mathrm{mCi} / \mathrm{mg})$ were from the Radiochemical Centre, Amersham, Bucks.

Media. These were as described by Johnston \& Dyke (I97I) except that for the radioactive labelling experiments cells were grown in modified Kloos \& Pattee medium (KP medium) (Kloos \& Pattee, 1965). KP medium contains in I 1 of distilled water: $\mathrm{K}_{2} \mathrm{HPO}_{4}$, $7 \mathrm{~g} ; \mathrm{KH}_{2} \mathrm{PO}_{4}, 2 \mathrm{~g} ; \mathrm{MgSO}_{4} \cdot{ }_{7} \mathrm{H}_{2} \mathrm{O}$, $0.1 \mathrm{~g} ;\left(\mathrm{NH}_{4}\right)_{2} \mathrm{SO}_{4}$, I g; tri-sodium citrate, $0.5 \mathrm{~g}$; glycine, $50 \mathrm{mg}$; L-glutamic acid, I00 $\mathrm{mg}$; L-aspartic acid, $90 \mathrm{mg}$; L-serine, $30 \mathrm{mg}$; L-methionine, $20 \mathrm{mg}$; L-cysteine, $20 \mathrm{mg}$; L-alanine, $60 \mathrm{mg}$; L-lysine $\mathrm{HCl}, 50 \mathrm{mg}$; L-arginine $\mathrm{HCl}, 50 \mathrm{mg}$; L-threonine, $30 \mathrm{mg}$; L-phenylalanine, $40 \mathrm{mg}$; L-tryptophan, Io $\mathrm{mg}$; L-leucine, $90 \mathrm{mg}$; L-isoleucine, $30 \mathrm{mg}$; L-proline, $80 \mathrm{mg}$; L-valine, $80 \mathrm{mg}$; L-histine, $40 \mathrm{mg}$; nicotinic acid, I $\mathrm{mg}$; thiamine- $\mathrm{HCl}$, I $\mathrm{mg}$; sodium thioglycollate, $200 \mathrm{mg}$; glucose, $5 \mathrm{~g}$; and $0.04 \mathrm{ml}$ of a trace element solution.

The trace element solution contained (per litre): $\mathrm{CuSO}_{4} \cdot 5 \mathrm{H}_{2} \mathrm{O}, 2.5 \mathrm{~g} ; \mathrm{ZnSO}_{4} \cdot 7 \mathrm{H}_{2} \mathrm{O}$, $2.5 \mathrm{~g} ; \mathrm{FeSO}_{4} \cdot 7 \mathrm{H}_{2} \mathrm{O}, 2.5 \mathrm{~g} ; \mathrm{MnCl}_{2} \cdot 4 \mathrm{H}_{2} \mathrm{O}, \mathrm{I} \cdot 0 \mathrm{~g}$; and conc. $\mathrm{HCl}, 50 \mathrm{ml}$.

Nomenclature. This was described by Johnston \& Dyke (I971). Chromosomal genes are represented without parentheses, while genes carried on a plasmid are within parentheses, ( ). Deletion of gene(s) is represented by their inclusion within brackets, [ ].

Transduction procedure. Transductions were carried out as previously described (Johnston \& Dyke, I97I). Selection was on casein hydrolysate-yeast agar (CY agar) with additions as follows: for erythromycin resistance, $20 \mu \mathrm{g}$ erythromycin/ml (CY-ero agar): for cadmium resistance, $13.3 \mu \mathrm{g}$ cadmium acetate $/ \mathrm{ml}$ (CY-cad agar); for penicillin resistance, $0.2 \mu \mathrm{g}$ benzyl penicillin/ml (CY-pen agar).

Plate assay for penicillinase. A modification of the starch-iodine method of Perret was used (Dyke, Jevons \& Parker, 1966).

Irradiation of cells and phage. An Hanovia 'Chromatolite' ultraviolet lamp was used. The material to be irradiated, either exponentially growing cells in tryptone soya broth (TSB) or phage suspended in TSB diluted with two parts phage buffer (Novick, I963), was I $2 \mathrm{~cm}$ from the lamp.

Bacteriophage. The bacteriophage was phage 80 of the International Staphylococcal Phage Typing Set. Phage was propagated as described by Novick (I963).

Bacteria and plasmids. Table I lists some of the characteristics of the bacterial strains used.

Strain PS80(NCTC9789) is the propagating strain for phage 80 of the International Phage Typing Set. This strain has a chromosomal pen $Z$ gene and plasmid asa cad mer genes (Asheshov, I966). Phage propagated on PS80 can sometimes cotransduce the asa cad mer and penZ genes and this linkage group behaves as a plasmid in the recipient (Asheshov, 1969). Strain PS80.d was derived by elimination of plasmid $\left(\mathrm{PI}_{\mathbf{9 7 8 9}}\right)$ and by deletion of the penI penZ genes from the chromosome (Johnston \& Dyke, 197I).

The temperature-sensitive plasmid was that described by Johnston \& Dyke (I97I) and designated ( $\mathrm{PI}_{9789}$ seg-I penI penZ). A brief summary of the properties of this mutant is as follows: it was derived by mutagenesis of strain PS80[penI penZ]( $\mathrm{PI}_{9789}$ penI penZ); it is phenotypically temperature sensitive for production of penicillinase; this defect is believed to be in replication of the plasmid, with reduction of replication at $42{ }^{\circ} \mathrm{C}$. In a different set of experiments it has been shown that the peak of radioactivity that corresponds to the 
Table I. Strains used and their nomenclature

\begin{tabular}{|c|c|c|c|c|c|c|c|c|c|c|c|}
\hline \multirow[b]{2}{*}{ Strain } & \multirow[b]{2}{*}{$\begin{array}{l}\text { Abbreviated } \\
\text { nomenclature }\end{array}$} & \multicolumn{3}{|c|}{$\begin{array}{l}\text { Chromosomal } \\
\text { genes }\end{array}$} & \multicolumn{7}{|c|}{ Plasmid genes } \\
\hline & & & pen $Z$ & ero & penI & pen $Z$ & asa & cad & mer & ero & $\begin{array}{l}\text { Repli- } \\
\text { cation }\end{array}$ \\
\hline $\mathrm{PS} 80\left(\mathrm{PI}_{9789}\right)$ & - & + & + & - & - & - & + & + & + & - & Normal \\
\hline $\mathrm{PS} 80\left(\mathrm{PI}_{9799}\right.$ penI pen $\left.Z\right)$ & - & + & + & - & + & + & + & + & + & - & Normal \\
\hline PS80[penI penZ] & PS80.d & - & - & - & - & - & - & - & - & - & - \\
\hline $\begin{array}{l}\mathrm{PS} 80[\text { penI pen } Z] \\
\left(\mathrm{PI}_{9789} \text { penI pen } Z \text { ) }\right.\end{array}$ & $\begin{array}{l}\text { Ps80.d. } \\
\text { (PI }\end{array}$ & - & - & - & + & + & + & + & + & - & Normal \\
\hline $\begin{array}{l}\mathrm{PS} 80[\text { [penI pen } Z] \\
\left.\text { ( } \mathrm{PI}_{9789} \text { seg-I penI pen } Z\right)\end{array}$ & PS80.d.(SI) & - & - & - & + & + & + & + & + & - & TS* \\
\hline $\begin{array}{l}8325 \\
\left(\mathrm{PI}_{258} \text { penZ-40I cad-52) }\right.\end{array}$ & - & - & - & - & + & $40 I$ & + & 52 & + & + & Normal \\
\hline $1054\left(\mathrm{PI}_{1054}\right)$ & - & - & - & - & + & + & - & - & - & - & Normal \\
\hline $\begin{array}{l}\mathrm{PS} 80[\text { penI pen } Z] \\
\text { ( } \mathrm{PI}_{258} \text { penZ-40I cad-52) }\end{array}$ & $\begin{array}{l}\text { PS8o.d. } \\
\text { (PI }_{258} \text { penZ-40I cad- }\end{array}$ & $-52)$ & - & - & + & 401 & + & 52 & + & + & Normal \\
\hline 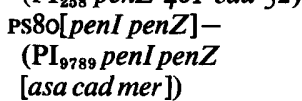 & $\begin{array}{l}\text { PS80.d.- } \\
\quad\left(\mathrm{PI}_{8788} \text { penI pen } Z\right. \\
\text { [asa cad mer }] \text { ) }\end{array}$ & - & - & - & + & + & - & - & - & - & Normal \\
\hline $\begin{array}{l}\mathrm{PS80}[\text { penI penZ }] \\
\left(\mathrm{PI}_{\text {ongo }} \text { seg-I) }\right.\end{array}$ & PS80.d.(PI ${ }_{9789}$ seg-I $)$ & - & - & - & - & - & + & + & + & - & TS* \\
\hline PS80[penI penZ]ero & Ps8o.d.ero & - & - & + & - & - & - & - & - & - & - \\
\hline $\mathrm{PS} 80[$ penI pen $Z]\left(\mathrm{PI}_{258}\right)$ & PS80.d.(PI $\left.{ }_{258}\right)$ & - & - & - & + & + & + & + & + & + & Normal \\
\hline
\end{tabular}

penicillinase plasmid DNA is absent in this strain when the culture is grown at $42{ }^{\circ} \mathrm{C}$ in the presence of radioactive precursors of DNA, but is present when the incubation is at $30^{\circ} \mathrm{C}$ (J. C. Measures, unpublished results). The observed lack of penicillinase production at high temperature is a result of loss of the plasmid from the bacteria after growth at $42{ }^{\circ} \mathrm{C}$. The mutation is solely plasmid linked.

We are indebted to Dr R. Novick for sending us strain $8325\left(\mathrm{PI}_{258}\right.$ penZ-4or cad-52). Phage 53 was propagated on this and used to transduce erythromycin resistance to strain I054 (Johnston \& Dyke, 197I); then phage 80 was propagated on one of these transductants and used to transduce erythromycin resistance to PS80.d, to give PS80.d.(PI ${ }_{258}$ penZ-40I cad-52). Ps80.d.( $\mathrm{PI}_{9789}$ penI penZ[asa cad mer]) was constructed as follows: phage 80 was propagated on $\mathrm{PS} 8 \mathrm{O}\left(\mathrm{PI}_{9789}\right.$ penI penZ) that had previously been irradiated with u.v. light and this phage preparation was used to transduce penicillin resistance to PS80.d. A cadmiumsensitive transductant was picked after replica plating to CY-cad agar and was also found to be sensitive to arsenate and mercury ions. To be sure that this penicillinase gene was plasmid borne, the stability of the gene during growth at $43{ }^{\circ} \mathrm{C}$ was determined. It was lost from the cell with a frequency characteristic of a plasmid gene. (After $4 \mathrm{~h}$ growth in TSB at $43^{\circ} \mathrm{C}$, $\mathrm{I} \cdot \mathbf{2} \%$ of 3480 colonies tested did not produce penicillinase.)

Strain PS80.d.( $\mathrm{PI}_{9789}$ seg-I) was constructed as follows: phage propagated on PS80.d.(SI) was irradiated with u.v. light for Io $s$ and then used to transduce cadmium resistance to PS8o.d. Transductants were tested for penicillinase production, and one that produced no penicillinase but was resistant to arsenate, cadmium and mercury ions and was temperaturesensitive for replication was selected.

Strain PS80.d.ero was constructed as follows: phage 80 propagated on PS80.d.( $\left(\mathrm{PI}_{258}\right)$ was irradiated with u.v. light for $45 \mathrm{~s}$ and then used to transduce erythromycin resistance to 
PS8o.d. A transductant producing no penicillinase and sensitive to arsenate, cadmium and mercury ions was selected for further study. The erythromycin resistance of this transductant is stable (after $8 \mathrm{~h}$ growth in TSB at $42{ }^{\circ} \mathrm{C}$, no erythromycin-sensitive colonies were found among 9484 examined; PS8o.d. $\left(\mathrm{PI}_{258}\right)$ gave $\mathrm{I} \cdot 9 \%$ erythromycin-sensitive colonies in a control experiment). Further, the transductant will accept a $\mathrm{PI}_{\mathbf{9 7 8 9}}$ plasmid at a tenfold higher frequency than will PS80.d.( $\mathrm{PI}_{258}$ penZ-40I cad-52). Since both $\mathrm{PI}_{258}$ and $\mathrm{PI}_{9789}$ belong to the same compatibility group, this result suggests that the compatibility has been lost. These results are consistent with a transposition of the ero gene from the plasmid to the chromosome (Novick, $1967 b$ ) or possibly some other replicon.

Estimation of the stability of the $S_{\mathrm{I}}$ plasmid in $\mathrm{PS} 80 . d$ and $a S_{\mathrm{I}}$ revertant at $42{ }^{\circ} \mathrm{C}$. Cells were grown in TSB at $30^{\circ} \mathrm{C}$ for $\mathrm{I} 8 \mathrm{~h}$. The $\mathrm{I} 8 \mathrm{~h}$ culture was diluted in fresh TSB to $5 \times 10^{5}$ colony forming units (c.f.u.)/ml, incubated at $42{ }^{\circ} \mathrm{C}$ for $4 \mathrm{~h}$ and then diluted and plated on $\mathrm{CY}$ agar. All plates were incubated for approx. $24 \mathrm{~h}$ at $30^{\circ} \mathrm{C}$ and then the proportion of penicillinase-negative colonies was determined with starch-iodine.

When the effect of ethidium bromide on loss was studied this procedure was modified as follows: the $18 \mathrm{~h}$ culture was diluted to $5 \times 10^{5} \mathrm{c}$.f.u. $/ \mathrm{ml}$ with fresh TSB, with and without $9 \times \mathrm{IO}^{-6} \mathrm{M}$-ethidium bromide. The cultures were then incubated for $5 \mathrm{~h}$ at $42^{\circ} \mathrm{C}$ and afterwards diluted and plated for estimation of the proportion of penicillinase-negative colonies as above.

$D N A$-labelling. Cultures were grown for at least two generations in KP medium supplemented with $250 \mu \mathrm{g}$ 2-deoxyadenosine/ml (Boyce \& Setlow, 1962) plus either 6- $\left[{ }^{3} \mathrm{H}\right]$ thymidine at $5 \mu \mathrm{Ci} / \mathrm{ml}$ or $2-\left[{ }^{14} \mathrm{C}\right]$ thymidine at $\mathrm{I} \mu \mathrm{Ci} / \mathrm{ml}$. Cells were harvested at an $E_{675} \mathrm{~nm}$ of 0.8 , equivalent to $2 \times 10^{8}$ c.f.u. $/ \mathrm{ml}$.

Sucrose gradient velocity centrifugation. A suspension of $2.5 \times 10^{9}$ cells $/ \mathrm{ml}$ PNE buffer (0.06 M- $\mathrm{KH}_{2} \mathrm{PO}_{4} ; 0.04 \mathrm{M}-\mathrm{K}_{2} \mathrm{HPO}_{4} ; 0 . \mathrm{I} \mathrm{M}-\mathrm{NaCl} ; 0.0 \mathrm{I}$ M-ethylene diamine tetra-acetate; pH 7.4) was treated with $\mathrm{I} 5 \mu \mathrm{g}$ lysostaphin $/ \mathrm{ml}$ for $\mathrm{Io} \min$ at $37^{\circ} \mathrm{C}$. The suspension was rapidly frozen and thawed and incubated for $30 \mathrm{~min}$ at $37^{\circ} \mathrm{C}$ to complete the lysis.

Linear gradients $(4.9 \mathrm{ml})$ were prepared by means of a two-chamber mixing device from Io and $40 \%(\mathrm{w} / \mathrm{v})$ sucrose in PNE buffer over a shelf of $0.5 \mathrm{ml}$ of a solution of $\mathrm{CsCl}(3.4 \mathrm{~g}$ $\mathrm{CsCl}$ in $3 \mathrm{ml} 50 \%(\mathrm{w} / \mathrm{v})$ sucrose in PNE buffer) in cellulose nitrate tubes. The gradients were stored at $2{ }^{\circ} \mathrm{C}$ for $2 \mathrm{~h}$.

A sample (0.1 ml) of the cell lysate was carefully layered on to the top of the gradient and the tubes were centrifuged in a SW50.I rotor in a Spinco Model L2-65B centrifuge at $40000 \mathrm{rev} . / \mathrm{min}$ for $3 \mathrm{~h}$ at $5{ }^{\circ} \mathrm{C}$. The centrifuge was braked to $5000 \mathrm{rev} . / \mathrm{min}$ and allowed to coast to a stop.

Gradients were fractionated by puncturing the bottom of the tube with a stainless steel needle. Two-drop fractions were collected on Whatman Paper Chromedia GF82. This paper was soaked in $5 \%(\mathrm{w} / \mathrm{v})$ trichloroacetic acid (TCA) at $2{ }^{\circ} \mathrm{C}$ for $20 \mathrm{~min}$, washed with $5 \%$ $(w / v)$ TCA and then with ethanol by suction on a porous polythene strip. The washed papers were dried at $80{ }^{\circ} \mathrm{C}$ in vacuo for 30 min and then inserted into glass vials with $2.5 \mathrm{ml} \mathrm{2-(4-}$ t-butylphenyl)-5-(4-biphenyl)-I,3,4-oxydiazole (butyl PBD; $5 \mathrm{~g} / \mathrm{l}$ in toluene) for determination of radioactivity.

\section{RESULTS}

\section{Reversion to temperature stability of the temperature-sensitive plasmid $S_{\mathrm{I}}$}

When $10^{6}$ c.f.u. of a strain carrying the temperature-sensitive plasmid are plated on CYcad agar and then incubated at $42^{\circ} \mathrm{C}$ for $18 \mathrm{~h}$, on average some 33 cadmium-resistant colonies appear. The experiment has been repeated many times and cadmium-resistant 
Table 2. The stability at $42{ }^{\circ} \mathrm{C}$ of the penicillinase genes of Ps80.d harbouring plasmid $P_{9789}$ penI penZ, the $S_{1}$ plasmid, and a SI revertant

\begin{tabular}{cccc} 
Grown at & \multicolumn{3}{c}{ Penicillinase-negative colonies $(\%)$} \\
$42^{\circ} \mathrm{C}$ for (h) & $\overbrace{\mathrm{PI}_{9789} \text { penI penZ }}$ & SI plasmid & SI revertant \\
0 & 0.8 & $\mathbf{I} \cdot 8$ & 0.12 \\
4 & $\mathrm{I} \cdot 0$ & $63 \cdot 0$ & 0.34
\end{tabular}

At least 1000 colonies were tested for each of the figures given in the table.

Table 3. The stability at $42{ }^{\circ} \mathrm{C}$ of penicillinase genes of Ps80.d harbouring plasmid $\mathrm{PI}_{\mathbf{9 7 8 9}}$ penI pen $Z, S_{\mathrm{I}}$ plasmid, and $S_{\mathrm{I}}$ revertant, in the presence and absence of $9 \times \mathrm{IO}^{-6} \mathrm{M}$ ethidium bromide

\begin{tabular}{|c|c|c|c|c|c|c|}
\hline \multirow{3}{*}{$\begin{array}{c}\text { Grown at } \\
42^{\circ} \mathrm{C} \text { for }(\mathrm{h})\end{array}$} & \multicolumn{6}{|c|}{ Penicillinase-negative colonies $(\%)$} \\
\hline & \multicolumn{2}{|c|}{$\mathrm{PI}_{9789}$ penI pen $Z$} & \multicolumn{2}{|c|}{ SI plasmid } & \multicolumn{2}{|c|}{ SI mutant } \\
\hline & $-\mathrm{EtBr}$ & $+\mathrm{EtBr}$ & $-\mathrm{EtBr}$ & $+\mathrm{EtBr}$ & $-\mathrm{EtBr}$ & $+\mathrm{EtBr}$ \\
\hline 0 & 0.8 & 0.8 & $\mathrm{I} \cdot 7$ & $I \cdot 7$ & 0.0 & $0 \cdot 0$ \\
\hline 5 & $I \cdot I I I$ & 16.0 & $56 \cdot 7$ & $68 \cdot 5$ & 0.105 & 0.17 \\
\hline
\end{tabular}

$\mathrm{EtBr}=$ ethidium bromide.

At least 3000 colonies were tested for each of the figures given in the table.

colonies were always found. Cadmium-resistant colonies obtained in this way will be called revertants. Under the same conditions, $10^{6}$ c.f.u. of $\mathrm{PS}^{80 . d .}\left(\mathrm{PI}_{9789}\right.$ penI penZ) gave confluent growth on the plate.

The stability of the penicillinase genes in these cadmium-resistant colonies has been measured at $42{ }^{\circ} \mathrm{C}$ and compared with the stability of both wild-type and the derived temperature-sensitive plasmid. The results (Table 2) indicate that the penicillinase genes are very much more stable than the penicillinase gene in the SI plasmid and of rather greater stability than the $\mathrm{PI}_{\mathbf{9 7 8 9}}$ penI penZ plasmid. Loss of penicillinase is assumed to be equated to loss of the plasmid since in all cases tested ( $>$ 100 for each plasmid) resistance to cadmium ions was also lost.

Growth of plasmid-containing strains of Staphylococcus aureus in the presence of ethidium bromide results in loss of the plasmid (Bouanchaud, Scavizzi \& Chabbert, I968). The experiment on stability was repeated in the presence of $9 \times 10^{-6} \mathrm{M}$-ethidium bromide. The results (Table 3) confirm those of Table 2 in that the cadmium-resistant temperaturestable revertant loses its cadmium resistance at a low rate compared with the temperaturesensitive plasmid. The revertant is more stable than the parent plasmid-containing strain.

\section{Transduction of cadmium resistance from revertants}

Phage 80 propagated on ten independently isolated revertants and used to transduce cadmium resistance to Ps80.d gave transductants that were all (more than 1000 tested for each transduction) temperature sensitive for penicillinase production. Thus the temperaturesensitive mutation is present but masked in the revertants. 


\section{Interaction of revertants with a second plasmid}

When a second plasmid is transduced into a Staphylococcus aureus that already harbours a plasmid of the same compatibility type, then the second plasmid may establish itself in the recipient either by recombination with the resident plasmid or by displacing it (Richmond, 1968).

* Phage 80 propagated on PS80.d. $\left(\mathrm{PI}_{258}\right.$ penZ-40I cad-52) was used to transduce erythromycin resistance into a revertant of PS8o.d.(SI). Transductant colonies were isolated, grown in TSB medium at $30^{\circ} \mathrm{C}$, then subcultured to fresh TSB and growth continued at $30{ }^{\circ} \mathrm{C}$. After a total of 14 generations, the culture was plated for single colonies, the plates incubated at $30{ }^{\circ} \mathrm{C}$, and the colonies tested for penicillinase production and for resistance to erythromycin. All colonies were resistant to erythromycin and $2.4 \%$ had lost the ability to produce penicillinase. The transductants are thus moderately stable and the small loss of the revertant phenotype is not associated with loss of the superinfecting plasmid.

In a second transduction, phage 80 was grown on PS80.d. $\left(\mathrm{PI}_{9789}\right.$ seg-I penI penZ) and used to transduce penicillin-resistance into a revertant of PS80.d.(PI $\mathrm{I}_{9789}$ seg-I) [PS80.d.(PI ${ }_{9789}$ seg-I) has the penicillinase gene deleted]. The transductants were tested for stability of penicillinase production as described for Table 2 . After $4 \mathrm{~h}$ growth in TSB medium at $42{ }^{\circ} \mathrm{C}$ followed by plating and incubation of plates at $30{ }^{\circ} \mathrm{C}$, some $57 \%$ of the colonies were penicillinase negative. All 20 penicillinase-negative colonies tested were resistant to cadmium ions. The cells had thus lost the temperature-sensitive plasmid but had retained the revertant cadmium resistance.

\section{Association between revertant cadmium resistance and a chromosomal gene}

If the reversion to temperature stability is due to integration into a different replicon, such as the chromosome, then it should be possible to obtain co-transduction of a plasmid gene and a chromosomal gene. There is good evidence that the pen $Z$ gene is chromosomal in strain PS80 (Asheshov, 1966) so we looked for linkage between the penicillinase gene and cadmium resistance in a revertant derived from PS80.(PI ${ }_{9789}$ seg- $I$ ). Phage 80 was propagated on two of the revertants; one of the phage preparations gave no co-transduction of cad and penZ (I 73 transductants tested) but the other gave $100 \%$ co-transduction of these genes (I53 transductants tested) and all the transductants were temperature sensitive for both penicillinase and cadmium resistance. In a control when phage is propagated directly on PS80. $\left(\mathrm{PI}_{\mathbf{9 7 8 9}}\right.$ seg- $\left.I\right)$ there is no co-transduction of cadmium resistance and penicillinase.

The erythromycin-resistance gene can be transposed from the plasmid to another replicon - probably the chromosome (Novick, I967 b). We have constructed such a strain (see Methods). It is sensitive to cadmium, arsenate and mercury and does not produce penicillinase A.( $\mathrm{PI}_{\mathbf{9 7 8 9}}$ seg-I penI penZ) plasmid was transduced into this strain PS80.d.ero selecting for cadmium resistance, and then temperature-stable revertants were obtained in the usual way. Phage 80 was propagated on a number of these revertants and used to transduce erythromycin resistance to PS80.d; all transductants were tested for co-transduction of the pen $Z$ gene. Phage propagated on 4 of 32 revertants show co-transduction of the two markers, but at different frequencies: $0 \cdot 6,3 \cdot 7,8 \cdot 0$ and $14.6 \%$ of the erythromycin-resistant transductants possessed the pen $Z$ gene as well, and these were all temperature sensitive. All the transductants that co-transduced penicillin resistance and erythromycin resistance had plasmids that were temperature sensitive in that both resistances were lost together at very 


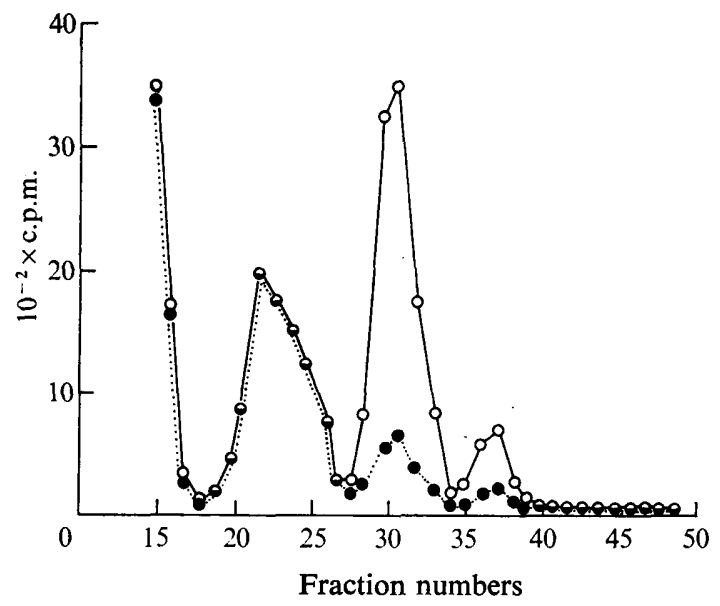

Fig. I. Velocity sedimentation of DNA from $S$. aureus PS80.d.SI and PS80.d.SI revertant. Cells of PS80.d.SI were grown in the presence of $\left[{ }^{3} \mathrm{H}\right]$ thymidine at $30^{\circ} \mathrm{C}$ and cells of a cadmium-resistant revertant derived from PS80.d.SI were grown at $30{ }^{\circ} \mathrm{C}$ in the presence of $\left[{ }^{14} \mathrm{C}\right]$ thymidine. The cells were mixed, lysed with lysostaphin, and $0.1 \mathrm{ml}$ of the lysate placed on top of a 10 to $40 \%(\mathrm{w} / \mathrm{v})$ linear sucrose gradient $(4.9 \mathrm{ml})$. The gradient was centrifuged at $5^{\circ} \mathrm{C}$ and $40000 \mathrm{rev} . / \mathrm{min}$ in a Spinco model L2-65B with a SW50.I rotor for $3 \mathrm{~h}$. About 50 fractions were obtained from each gradient and the amount of radioactivity precipitated by cold $5 \%(\mathrm{w} / \mathrm{v})$ trichloracetic acid was determined for each fraction. The c.p.m. have been adjusted so that the amount of radioactivity sedimenting to the bottom of the gradient is the same for both ${ }^{14} \mathrm{C}$ and ${ }^{3} \mathrm{H}$. O-O, ${ }^{3} \mathrm{H}$-radioactivity (PS80.d.SI); -..... ${ }^{14} \mathrm{C}$-radioactivity (Ps8o.d.S I revertant).

high frequency during growth at $42{ }^{\circ} \mathrm{C}$. Phage propagated on the remaining 28 revertants did not co-transduce ero and penZ.

\section{Physical studies on a revertant}

A culture of $\mathrm{PS} 80 . d .\left(\mathrm{PI}_{\mathbf{9 7 8 9}}\right.$ seg-I penI penZ) that had been labelled with $\left[{ }^{3} \mathrm{H}\right]$ thymidine at $30^{\circ} \mathrm{C}$ was mixed with a culture of a revertant of the same strain that had been grown in $\left[{ }^{14} \mathrm{C}\right]$ thymidine at $30{ }^{\circ} \mathrm{C}$. The mixture was lysed as described in Methods and a sample placed on top of a 5 to $40 \%$ sucrose gradient and centrifuged.

Fractions from the gradients were collected, precipitated with $5 \%$ cold trichloroacetic acid and radioactivity determined as described in Methods. The results (Fig. I) show that there is very little radioactivity present in the peaks corresponding to the penicillinase plasmid for the revertant. The position of the penicillinase plasmid in this system has been extensively studied (J. C. Measures, unpublished).

\section{DISCUSSION}

The possible mechanisms that might account for the loss of temperature sensitivity of the plasmid are either reversion or suppression. Reversion is ruled out because it has been shown that the temperature-sensitive mutation is still present in the revertants so that the mutation is suppressed and not reverted.

There are several ways in which suppression might operate: (i) a second mutation such as a deletion or frame-shift on the plasmid; (ii) a second mutation on some other DNA element such as the chromosome; (iii) an integration of the plasmid into some other replicon - such an integration might be specific in that the integration disrupts a gene necessary for the expression of the temperature sensitivity. 
The first explanation is ruled out since transduction of cadmium resistance from a revertant to a PS80.d gave rise to temperature-sensitive transductants. The plasmid thus retains the temperature-sensitive mutation and does not carry a suppressor mutation.

The second explanation seems improbable since it has been shown that a second plasmid, isogenic for the temperature-sensitive defect, retains its temperature sensitivity in the revertant. There is thus no cytoplasmic factor, specified by some other piece of DNA, capable of suppressing the defect in the plasmid.

We are thus left with the third possibility, that of integration into some other replicon. There is no rigorous evidence for this mechanism but there are several pieces of evidence that support the possibility of integration.

First, we have evidence of linkage between the cadmium-resistance gene of the plasmid and a chromosomal penicillinase gene in the revertant. This linkage is unlikely to be a fortuitous association between the two genes during replication since in one case there is $100 \%$ co-transduction. The fact that there was no co-transduction in the other revertant tested suggests that there is no one specific region of the chromosome into which the plasmid must integrate. This latter conclusion is supported by the evidence for linkage between the plasmid penicillinase gene and the chromosomal erythromycin gene since these two genes are cotransducible in four revertants but not in a further twenty-eight. It would be more convincing to show that there is linkage between a plasmid gene and an auxotrophic marker. Experiments are in progress to investigate this possibility.

Secondly, we have shown from the sucrose gradient results that there is very little, if any, DNA that behaves as a penicillinase plasmid in a revertant. This is evidence that the sedimentation properties of the plasmid DNA are changed but it does not prove that the plasmid DNA is integrated into the chromosome or any other replicon.

Thirdly, we have been able to construct a plasmid diploid in which two normally incompatible plasmids co-exist. The experiments reported in this paper suggest that the two plasmids are physically separate and are not associated diploids (see Richmond, I968). Thus either plasmid can be lost without affecting the other. A possible interpretation is that there is a site essential for replication of the plasmid and that in the revertant this site has become vacant and so can be used by the normally incompatible plasmid. There is no good evidence for such an interpretation.

One of our main pieces of evidence depends on the supposition that the ero gene is chromosomal in Ps8o.d.ero. All our evidence is that the ero gene is not on a plasmid in this strain, but it is possible that it is on a plasmid for a small part of the cell cycle or in a small proportion of the population and that our methods do not detect it. Thus the observed linkage between the ero gene and the SI plasmid in some revertants could have occurred while the ero gene was extrachromosomal rather than while the ero was in the chromosome. It could be argued that the small amount of plasmid DNA found in the gradients prepared from revertants is due to this small fraction of plasmid in the cultures, rather than our explanation which is that some excision of the plasmid has occurred.

We suggest that all this evidence leads to the hypothesis that the most likely cause of suppression of the temperature-sensitive mutation in some of the revertants is integration into some other replicon, very probably the chromosome. Further evidence is required before this can be more than a very tentative hypothesis. It is unlikely that the hypothesis applies to every revertant, since true reversion and other forms of suppression will occur, but we suggest that integration is one form of reversion in this system. 
L. H. Johnston was supported by a Rhodes Scholarship for the duration of this work. We thank Mr J. C. Measures for the sucrose gradient results.

\section{REFERENCES}

AsHeshov, E. H. (1966). Chromosomal location of the genetic elements controlling penicillinase production in a strain of Staphylococcus aureus. Nature, London 210, 804-806.

Asheshov, E. H. (1969). The genetics of penicillinase production in Staphylococcus aureus strain PS80. Journal of General Microbiology 59, 289-30I.

Bouanchaud, D. H., Scavizzi, M. R. \& Chabbert, Y. A. (I968). Elimination by ethidium bromide of antibiotic resistance in enterobacteria and staphylococci. Journal of General Microbiology 54, 417-425.

Boyce, R. P. \& SeTLOW, R. B. (1962). A simple method of increasing the incorporation of thymidine into the deoxyribonucleic acid of Escherichia coli. Biochimica et biophysica acta 6r, 6I 8-620.

Dyke, K. G. H., Jevons, M. P. \& PARker, M. T. (I966). Penicillinase production and intrinsic resistance to penicillins in Staphylococcus aureus. Lancet i, 835-838.

JACOB, F., BRENNER, S. \& CUZIN, F. (1963). On the regulation of DNA replication in bacteria. Cold Spring Harbor Symposia on Quantitative Biology 28, 329-348.

Johnston, L. H. \& DYke, K. G. H. (I97I). Stability of penicillinase plasmids in Staphylococcus aureus. Journal of Bacteriology x07, 68-73.

Kloos, W. E. \& PATteE, P. A. (1965). A biochemical characterization of histidine-dependent mutants of Staphylococcus aureus. Journal of General Microbiology 39, 185-194.

Mitsulhashi, S., Hashimoto, H., Kono, M. \& Morimura, M. (I963). Drug resistance of staphylococci. II. Joint elimination and joint transduction of penicillinase production and resistance to macrolide antibiotics. Journal of Bacteriology 89, 988-992.

Novick, R. P. (1963). Analysis by transduction of mutations affecting penicillinase formation in Staphylococcus aureus. Journal of General Microbiology 33, $12 \mathrm{I}-\mathrm{I} 36$.

Novick, R. P. (1967a). Penicillinase plasmids of Staphylococcus aureus. Federation Proceedings 26, $29-38$.

Novick, R. P. $(1967 b)$. Mutations affecting maintenance and replication of penicillinase plasmids in Staphylococcus aureus. In Proceedings of the Fifth International Congress of Chemotherapy, Vienna, pp. 269-273.

Novick, R. P. \& Roth, C. (1968). Plasmid-linked resistance to inorganic salts in Staphylococcus aureus. Journal of Bacteriology 95, 1335-1342.

RichMOND, M.H.(1968). The plasmids of Staphylococcus aureus and their relation to other extrachromosomal elements in bacteria. Advances in Microbial Physiology 2, 43-88. 